\title{
Impact of System of Rice Intensification (SRI) Components on Nutrient Content, Nutrient Uptake, Soil Parameters and Economics over Conventional Puddled Transplanted Rice
}

\author{
Rahul Kumar', Manish Raj ${ }^{1 *}$, Kanhaiya Lal ${ }^{1}$, Aditya Shri ${ }^{1}$, \\ Ajay Kumar ${ }^{1}$ and Priyanka Kumari ${ }^{2}$
}

${ }^{1}$ Department of Agronomy, ${ }^{2}$ Department of Soil Science and Agricultural Chemistry, Bihar Agricultural University, Sabour, Bhagalpur, 813210, Bihar, India

*Corresponding author

\section{A B S T R A C T}

\begin{tabular}{l} 
K e y w o r d s \\
$\begin{array}{l}\text { System of Rice } \\
\text { Intensification, } \\
\text { Transplanted rice, } \\
\text { CPTR }\end{array}$ \\
\hline Article Info \\
$\begin{array}{l}\text { Accepted: } \\
04 \text { October } 2020 \\
\text { Available Online: } \\
10 \text { November } 2020\end{array}$ \\
\hline
\end{tabular}

Keywords

System of Rice

Transplanted rice, CPTR

\section{Introduction}

Globally rice spread in an area of about 216 million hectares (mha) with the production and productivity of 655 million tonnes $(\mathrm{mt})$ and $3004 \mathrm{~kg} \mathrm{ha}^{-1}$ respectively. Rice stands second position in area and production in world (FAOSTAT 2015). In India rice is grown in an area of about 43.19 mha having $110.15 \mathrm{mt}$ production of and $2550 \mathrm{~kg} \mathrm{ha}^{-1}$ productivity (Annual report of Ministry of Agriculture and Farmers' Welfare, 2017-18).

\begin{abstract}
An experiment was conducted at research farm of Bihar Agricultural University, Sabour, Bhagalpur, India during Kharif 2019 to study the impact of system of rice intensification (SRI) components on nutrient content and uptake, soil parameters and economics over conventional puddled transplanted rice. The experiment was laid out in completely randomized block design with eight treatments replicated thrice. The first treatment was conventional puddle transplanted rice (CPTR), thereafter six treatments were CPTR with an addition component of SRI in each treatment and the last treatment was sole SRI. Results revealed that the highest gross return (Rs $122650 \mathrm{ha}^{-1}$ ) was recorded in the SRI, which was statistically at par with CPTR with 12 days seedling. The highest net return (Rs $78975 \mathrm{ha}^{-1}$ ) was recorded in the CPTR with 12 days seedling, and highest B:C ratio obtained (2.12) in CPTR with 12 days seedling. Among all the treatments the N, P and K content in grain was recorded no significant difference. The highest $\mathrm{N}, \mathrm{P}$ and $\mathrm{K}$ uptake in grain and straw were recorded with SRI over other treatments.
\end{abstract}


efficiency. Excess water, transplanting shock, use of older seedlings and inappropriate spacing are the major concerns of traditional transplanted system which leads to low productivity of rice. To sustain the productivity of rice, we have to practice cultivation methods in which all these challenges will be resolved. System of rice intensification (SRI) has the potential to meet these challenges because it has the capacity to increase the productivity with less water requirement. The technique, SRI was firstly used by the farmer of Madagascar in 1984.In India, SRI technology was spread with a goal of increasing the productivity of irrigated rice with profuse tillering, higher fertile gains, greater root growth and the soil microbial abundance and diversity (Kumar and Shivay, 2004).

The SRI system is found to be an efficient alternative to increase the rice production as it requires less water, less seed, reducing cost of cultivation and saving labour over time. Basically under SRI technique the six components are very important viz. early transplanting (8-12 days), carefully transplanting with 1 seedling hill ${ }^{-1}$, wider spacing $(25 \mathrm{~cm} \times 25 \mathrm{~cm})$, weeding and aeration (mechanical rotating hoe/cono weeder), water management (alternate wetting and drying) and application of farm yard manure (FYM). The SRI system improves the productivity of rice in a sustainable way. Yield obtained in SRI system is generally high because of less competition faced by plants as well as better root development thanks to organized spacing, more sunlight interception, enhanced soil microbial population, high organic matter content and better nutrient \& water availability. The weeds are also controlled easily with the help of mechanical hand weeder which helps in soil aeration, reduces the green house gases emissions and increases the productivity of rice in sustainable way. In SRI system the implementation of alternate wetting and drying (AWD) enhances the water use efficiencies and may reduces 30-40 $\%$ of water wastages from traditional methods (Latif, 2010). But the researchers faced still difficulties in acute implementation of all the techniques and trying to search the most important component among the six components of SRI. Based on the water table, depth and soil type, the AWD was found very complicated for the farmers as the water level lower down to about $5-10 \mathrm{~cm}$ and $5-15 \mathrm{~cm}$ from soil surface during before flowering and grain filling of rice, respectively (Bouman et al., 2007; Kishore et al., 2017). So, partial implementation of SRI technique in conventional practice may found to be beneficial in transplanted kharif rice (Palanisami et al., 2013; Reuben et al., 2016).

\section{Materials and Methods}

The investigation was conducted at the research farm of Bihar Agricultural University, Sabour, Bhagalpur, India during 2019 kharif season. Bhagalpur stationed south of the river Ganges and representing of Agroclimatic Zone III-A which is situated at latitude of $25^{\circ} 15^{\prime} 40^{\prime \prime} \mathrm{N}$ and $87^{\circ} 2^{\prime} 42^{\prime \prime} \mathrm{E}$ longitude with altitude of 52.73 meter above mean sea level. The soil of the experimental plot was sandy clay loam in nature $(50.9 \%$ sand, $21.1 \%$ silt and $28.3 \%$ clay) (International pipette Method, Piper (1950) having low in fertility status $(192.5 \mathrm{~kg}$ available $\mathrm{N} \mathrm{ha}{ }^{-1}, 17.8 \mathrm{~kg}$ available $\mathrm{P} \mathrm{ha}^{-1}$ and $123.8 \mathrm{~kg}$ available $\mathrm{K} \mathrm{ha}^{-1}$ ), neutral condition in nature $(\mathrm{pH}=7.4)$. The initial soil sample was collected before the experimentation at 0 $15 \mathrm{~cm}$ soil depth to get the soil fertility status.

The experiment was laid out in completely randomized block design with eight treatments replicated thrice. The details of treatments are given in table 1 . The size of individual plot was $6 \mathrm{~m} \times 3 \mathrm{~m}$. The first treatment was conventional puddled 
transplanted rice (CPTR), thereafter six treatments were also CPTR with an addition component of SRI in each treatment and the last treatment was sole SRI. The recommended dose of fertilizer was 120:60:40 kg N:P $\mathrm{P}_{2}: \mathrm{K}_{2} \mathrm{O} \mathrm{ha}^{-1}$ and the sources were Urea, Di Ammonium Phosphate, Muriate of Potash and vermi-compost. In CPTR the 22 days old seedlings were used with general spacing was maintained as $20 \mathrm{~cm}$ $\times 15 \mathrm{~cm}$. In treatments $\mathrm{T}_{5}$ and $\mathrm{T}_{8}$ the $50 \% \mathrm{~N}$ (60 $\mathrm{kg} \mathrm{N} \mathrm{ha}^{-1}$ ) was mitigated with vermicompost having $1.75 \% \mathrm{~N}$ and those plots were received @ 3.4 t vermi-compost ha ${ }^{-1}$ during final land preparation. All the treatments received full dose of $\mathrm{P}_{2} \mathrm{O}_{5}$ and $\mathrm{K}_{2} \mathrm{O}$ as basal dose i.e. one day before transplanting. The $\mathrm{N}$ fertilizer was applied in three split i.e. $40 \%$ as basal and remaining was applied in two equal split (30\%) at active tillering (25 DAT) and panicle initiation (45 DAT) stages. As the treatment $\mathrm{T}_{5}$ and $\mathrm{T}_{8}$ received vermi-compost as basal, here the $\mathrm{N}$ was applied in split as $25 \%$ in both the active tillering and panicle initiation stages. In the treatment $\mathrm{T}_{7}$ and $\mathrm{T}_{8}$, the mechanical rotating hoe was used twice for weed management and the others received one hand weeding and herbicide application as post emergence during the course of investigation. The details treatment combinations are given below.

\section{Crop variety}

The crop variety 'Sabour Shree' was released from Bihar Agricultural University, Sabour. It is generally recommended for long duration (145-150 days) with an average potential yield about $45-55 \mathrm{q} \mathrm{ha}^{-1}$.

\section{Statistical Analysis}

The data were analyzed statistically by applying "Analysis of Variance" (ANOVA) technique of completely randomized block design. The significance of different sources of variations was tested by error mean square of Fisher Snedecor's 'F' test at probability level 0.05. Standard error of mean (SEm \pm ) and least significant difference (LSD) at 5\% level of significance were worked out for each character and provided in the summary tables of the results to compare the difference between the treatment means (Table 1-5).

\section{Results and Discussion}

\section{Soil Parameters}

Among all the treatments, there were no significant differences in available N, P and $\mathrm{K}$ in soil after harvest of crop.

From the one year experimental findings the soil chemical properties did not differ significantly among the treatments. However CPTR with N-Organic:inorganic::50:50 (T5) has obtained highest available $\mathrm{N}$ in soil $\left(241 \mathrm{~kg} \mathrm{ha}^{-1}\right)$, available $\mathrm{P}_{2} \mathrm{O}_{5}\left(32.8 \mathrm{~kg} \mathrm{ha}^{-1}\right)$, availableK ${ }_{2} \mathrm{O}\left(141.4 \mathrm{~kg} \mathrm{ha}^{-1}\right)$ and organic carbon $(0.51 \%)$ at harvest. The inorganic (NPK) + Organic (vermi-compost) 50:50 has improved the soil fertility status because it may release the nutrients slowly. These statements are supported by Dass et al., (2015), Jat et al., (2015) and Mohanty et al., (2014) who found that application of inorganic + organic(50\% R.D.F. + 50\% R.D.F based on nitrogen requirement) in rice improved the nutrient content of the soil.

\section{Plant parameters}

\section{Nutrient content}

Among all the treatments the $\mathrm{N}$ content in grain was recorded no significant difference. However, the highest and lowest $\mathrm{N}$ content in grain was recorded $(1.17 \%)$ in $_{5}$ (CPTR with N-Organic: inorganic:: $50: 50)$ and $(1.13 \%)$ in $\mathrm{T}_{3}$ (CPTR with spacing of $25 \mathrm{~cm} \times 25 \mathrm{~cm}$ ) treatments respectively. Similarly, N content 
in straw after harvest recorded no significant difference among all the treatments. However, treatment $\mathrm{T}_{8}$ (Full component of SRI) and $\mathrm{T}_{1}$ (Conventional PTR) were given maximum and minimum content in straw that is $(0.76$ $\%)$ and $(0.68 \%)$ respectively.

Among all the treatments the $\mathrm{P}$ content in grain was recorded no significant difference. However, the highest and lowest $\mathrm{P}$ content in grain was recorded $(0.29 \%)$ in $_{5}$ (CPTR with N-Organic: inorganic:: 50:50) and (0.23 \%) in $\mathrm{T}_{7}$ (CPTR with weed management through Cono-weeder / mechanical rotating hoe) treatments respectively. Similarly, among all the treatments the $\mathrm{P}$ content in straw was recorded no significant difference. However, the highest and lowest $\mathrm{P}$ content in straw was recorded $(0.157 \%)$ in $\mathrm{T}_{8}$ (Full component of SRI) and $(0.133 \%)$ in $\mathrm{T}_{7}$ (CPTR with weed management through Cono-weeder/ mechanical rotating hoe) treatments respectively.

Similarly, K content in grain after harvest recorded, no significant difference was found among all the treatments. However, treatment $\mathrm{T}_{8}$ (Full component of SRI) and $\mathrm{T}_{6}$ (CPTR with Saturation water management) were given maximum and minimum content in grain that is $(0.31 \%)$ and $(0.23 \%)$ respectively. Similarly, recorded K content in straw after harvest recorded, no significant difference was found among all the treatments. However, treatment $\mathrm{T}_{8}$ (Full component of SRI) and $\mathrm{T}_{6}$ (CPTR with Saturation water management) were given maximum and minimum content in straw that is $(1.38 \%)$ and $(1.27 \%)$ respectively.

Among all the treatments the $\mathrm{N}$ content in grain was recorded no significant difference. However, the highest and lowest $\mathrm{N}$ content in grain was recorded $(1.17 \%)$ in $\mathrm{T}_{5}$ (CPTR with N-Organic: inorganic:: 50:50) and(1.13 $\%)$ in $\mathrm{T}_{3}(\mathrm{CPTR}$ with spacing of $25 \mathrm{~cm} \times 25 \mathrm{~cm})$ treatments respectively. Similarly, recorded N content in straw after harvest observed no significant difference was found among all the treatments. However, treatment $\mathrm{T}_{8}$ (Full component of SRI) and $\mathrm{T}_{1}$ (Conventional PTR) were given maximum and minimum content in straw that is $(0.76 \%)$ and $(0.68 \%)$, respectively. Among all the treatments the $\mathrm{P}$ content in grain was recorded no significant difference. However, the highest and lowest $\mathrm{P}$ content in grain was recorded $(0.29 \%)$ in $\mathrm{T}_{5}$ (CPTR with N-Organic: inorganic:: 50:50) and $(0.23 \%)$ in $\mathrm{T}_{7}$ (CPTR with weed management through mechanical rotating hoe) treatments respectively. Similarly, among all the treatments the $\mathrm{P}$ content in straw was recorded no significant difference. However, the highest and lowest $\mathrm{P}$ content in straw was recorded $(0.157 \%)$ in T8 (Full component of SRI) and $(0.133 \%)$ in $\mathrm{T}_{7}$ (CPTR with weed management through mechanical rotating hoe) treatments respectively. Similarly, $\mathrm{K}$ content in grain after harvest recorded, no significant difference was found among all the treatments. However, treatment $\mathrm{T}_{8}$ (Full component of SRI) and $\mathrm{T}_{6}$ (CPTR with Saturation water management) were given maximum and minimum content in grain that is $(0.31 \%)$ and $(0.23 \%)$, respectively. Similarly, recorded $\mathrm{K}$ content in straw after harvest recorded, no significant difference was found among all the treatments. However, treatment T8 (Full component of SRI) and T6 (CPTR with Saturation water management) were given maximum and minimum content in straw that is $(1.38 \%)$ and $(1.27 \%)$, respectively.

\section{Nutrient uptake}

The highest $\mathrm{N}$ uptake in grain $\left(70 \mathrm{~kg} \mathrm{ha}^{-1}\right)$ was recorded with SRI, which was found at par with CPTR with 12 days seedling $(64.7 \mathrm{~kg}$ $\left.\mathrm{ha}^{-1}\right)$ and CPTR with 1 seedling/hill $(61.7 \mathrm{~kg}$ $\left.\mathrm{ha}^{-1}\right)$. The lowest $\mathrm{N}$ uptake in grain $(50.8 \mathrm{~kg}$ 
$\mathrm{ha}^{-1}$ ) was recorded with CPTR with Saturation water management (AWD). The highest $\mathrm{N}$ uptake in straw $\left(50.5 \mathrm{~kg} \mathrm{ha}^{-1}\right)$ was recorded with SRI, which was found at par with CPTR with 12 days seedling $\left(46.9 \mathrm{~kg} \mathrm{ha}^{-1}\right)$ and CPTR with 1 seedling/hill $\left(45 \mathrm{~kg} \mathrm{ha}^{-1}\right)$. The lowest $\mathrm{N}$ uptake in straw $\left(38 \mathrm{~kg} \mathrm{ha}^{-1}\right)$ was recorded with CPTR with Saturation water management (AWD).The highest total $\mathrm{N}$ uptake $\left(120.5 \mathrm{~kg} \mathrm{ha}^{-1}\right)$ was recorded with SRI, which was found at par with CPTR with 12 days seedling $\left(111.6 \mathrm{~kg} \mathrm{ha}^{-1}\right)$.

The lowest total $\mathrm{N}$ uptake $\left(88.8 \mathrm{~kg} \mathrm{ha}^{-1}\right)$ was recorded with CPTR with Saturation water management (AWD).Similarly, the highest $\mathrm{P}$ uptake in grain $\left(15.3 \mathrm{~kg} \mathrm{ha}^{-1}\right)$ was recorded with SRI, which was found at par with CPTR with 12 days seedling (15.3 $\left.\mathrm{kg} \mathrm{ha}^{-1}\right)$, CPTR with 1 seedling/hill $\left(13.6 \mathrm{~kg} \mathrm{ha}^{-1}\right)$, CPTR with N-Organic: inorganic $\left(13.5 \mathrm{~kg} \mathrm{ha}^{-1}\right)$,CPTR with spacing of $25 \mathrm{~cm} \mathrm{x} 25 \mathrm{~cm}\left(12.5 \mathrm{~kg} \mathrm{ha}^{-1}\right)$ and conventional PTR $\left(12.2 \mathrm{~kg} \mathrm{ha}^{-1}\right)$. The lowest $\mathrm{P}$ uptake in grain $\left(10.4 \mathrm{~kg} \mathrm{ha}^{-1}\right)$ was recorded with CPTR with Saturation water management. The highest $\mathrm{P}$ uptake in straw $\left(10.5 \mathrm{~kg} \mathrm{ha}^{-1}\right)$ was recorded with SRI, which was found at par with CPTR with 12 days seedling $\left(9.3 \mathrm{~kg} \mathrm{ha}^{-1}\right), \quad$ CPTR with 1 seedling/hill $\left(8.8 \mathrm{~kg} \mathrm{ha}^{-1}\right)$ and CPTR with $\mathrm{N}$ -
Organic:inorganic::50:50 $\left(9.2 \mathrm{~kg} \mathrm{ha}{ }^{-1}\right)$. The lowest $\mathrm{P}$ uptake in straw $\left(7.3 \mathrm{~kg} \mathrm{ha}^{-1}\right)$ was recorded with CPTR with weed management through Conoweeder / mechanical rotating hoe. The highest total $\mathrm{P}$ uptake $\left(25.8 \mathrm{~kg} \mathrm{ha}^{-1}\right)$ was recorded with SRI, which was found at par with CPTR with 12 days seedling $(24.7 \mathrm{~kg}$ $\left.\mathrm{ha}^{-1}\right)$,CPTR with 1 seedling/hill $\left(22.3 \mathrm{~kg} \mathrm{ha}^{-1}\right)$ and CPTR with N-Organic: inorganic::50:50 $\left(22.7 \mathrm{~kg} \mathrm{ha}^{-1}\right)$.

The lowest total $\mathrm{P}$ uptake $\left(17.8 \mathrm{~kg} \mathrm{ha}^{-1}\right)$ was recorded with CPTR with Saturation water management (AWD). The highest $\mathrm{K}$ uptake in grain $\left(18.7 \mathrm{~kg} \mathrm{ha}^{-1}\right)$ was recorded with SRI, which was found at par with CPTR with 12 days seedling $\left(15.7 \mathrm{~kg} \mathrm{ha}^{-1)}\right.$. The lowest $\mathrm{K}$ uptake in grain $\left(10.3 \mathrm{~kg} \mathrm{ha}^{-1}\right)$ was recorded with CPTR with Saturation water management (AWD).Similarly, the highest K uptake in straw $\left(92.5 \mathrm{~kg} \mathrm{ha}^{-1}\right)$ was recorded with SRI, which was found at par with CPTR with 12 days seedling $\left(86.3 \mathrm{~kg} \mathrm{ha}^{-1}\right)$, CPTR with 1 seedling/hill $\left(88.3 \quad \mathrm{~kg} \quad \mathrm{ha}^{-1}\right)$, Conventional PTR (83.8 $\mathrm{kg} \mathrm{ha}^{-1}$ ) and CPTR with N-Organic: inorganic::50:50 $(80.6 \mathrm{~kg}$ $\mathrm{ha}^{-1)}$. The lowest $\mathrm{K}$ uptake in straw $(67.9 \mathrm{~kg}$ $\mathrm{ha}^{-1}$ ) was recorded with CPTR with Saturation water management (AWD).

Table.1 Treatment Details

\begin{tabular}{|l|l|}
\hline $\mathbf{T}_{\mathbf{1}}$ & Conventional puddled transplanted rice (CPTR) \\
\hline $\mathbf{T}_{\mathbf{2}}$ & CPTR using 12 days old seedlings (First component of SRI) \\
\hline $\mathbf{T}_{\mathbf{3}}$ & CPTR with spacing of $25 \mathrm{~cm} \times 25 \mathrm{~cm}$ (Second component of SRI) \\
\hline $\mathbf{T}_{\mathbf{4}}$ & CPTR with single seedling/hill (Third component of SRI) \\
\hline $\mathbf{T}_{\mathbf{5}}$ & CPTR with N-Organic:inorganic::50:50 (Fourth component of SRI) \\
\hline $\mathbf{T}_{\mathbf{6}}$ & $\begin{array}{l}\text { CPTR with Saturation water management i.e. alternating wetting and drying (Fifth } \\
\text { component of SRI) }\end{array}$ \\
\hline $\mathbf{T}_{\mathbf{7}}$ & $\begin{array}{l}\text { CPTR with weed management through Conoweeder / mechanical rotating hoe(Sixth } \\
\text { component of SRI) }\end{array}$ \\
\hline $\mathbf{T}_{\mathbf{8}}$ & $\begin{array}{l}\text { SRI }(\text { Spacing: } 25 \mathrm{~cm} \times 25 \mathrm{~cm}), \text { single seedling/hill, 12 days old seedling, N-Organic: } \\
\text { Inorganic }(50: 50), \text { Saturation water management, weed management through cono- } \\
\text { weeder/mechanical rotating hoe) }\end{array}$ \\
\hline
\end{tabular}


Table.2 Effect of different crop establishment method on the soil chemical properties of the rice crop

\begin{tabular}{|c|c|c|c|c|}
\hline \multirow[t]{2}{*}{ Treatments } & \multicolumn{4}{|c|}{ Soil chemical properties at harvest } \\
\hline & $\begin{array}{l}\text { Available } \\
\mathrm{N},\left(\mathrm{kg} \mathrm{ha}^{-1}\right)\end{array}$ & $\begin{array}{c}\text { Available } \\
\mathrm{P}_{2} \mathrm{O}_{5}\left(\mathrm{~kg} \mathrm{ha}^{-1}\right)\end{array}$ & $\begin{array}{c}\text { Available } \\
\mathrm{K}_{2} \mathrm{O}\left(\mathrm{kg} \mathrm{ha}^{-1}\right)\end{array}$ & $\begin{array}{l}\text { Organic } \\
\text { carbon, }(\%)\end{array}$ \\
\hline T1: Conventional PTR (CPTR) & 237 & 29.3 & 128.3 & 0.46 \\
\hline T2: CPTR with 12 days seedling & 228 & 28.9 & 126.6 & 0.43 \\
\hline T3: CPTR with spacing of $25 \mathrm{~cm} \times 25 \mathrm{~cm}$ & 224 & 28.1 & 131.6 & 0.48 \\
\hline T4: CPTR with 1 seedling/hill & 221 & 28.5 & 123.7 & 0.45 \\
\hline T5: CPTR with N-Organic:inorganic::50:50 & 241 & 32.8 & 141.4 & 0.51 \\
\hline $\begin{array}{l}\text { T6: CPTR with } \\
\text { management (AWD) }\end{array}$ & 236 & 29.9 & 127.8 & 0.48 \\
\hline $\begin{array}{l}\text { T7: CPTR with weed management through } \\
\text { mechanical rotating hoe }\end{array}$ & 224 & 31.8 & 123.4 & 0.46 \\
\hline T8: SRI & 230 & 29.2 & 129.9 & 0.51 \\
\hline $\operatorname{SEm}( \pm)$ & 8 & 3 & 10.32 & 0.03 \\
\hline $\operatorname{LSD}(p=0.05)$ & NS & NS & NS & NS \\
\hline
\end{tabular}

PTR $=$ Puddled transplanted rice; CPTR $=$ Conventional puddle transplanted rice; AWD = Alternate wetting and drying; SRI $=$ System of rice intensification; $\operatorname{SEm}( \pm)=$ Standard error of mean; LSD $=$ Least significant difference

Table.3 Effect of different crop establishment method on the nutrient content by grain and straw in rice crop

\begin{tabular}{|c|c|c|c|c|c|c|}
\hline \multirow[t]{3}{*}{ Treatments } & \multicolumn{6}{|c|}{ Nutrient content (\%) at harvest } \\
\hline & \multicolumn{3}{|c|}{ Grain } & \multicolumn{3}{|c|}{ Straw } \\
\hline & $\mathrm{N}, \%$ & $\mathrm{P}, \%$ & $\mathrm{~K}, \%$ & $\mathrm{~N}, \%$ & $\mathrm{P}, \%$ & $\mathrm{~K}, \%$ \\
\hline T1: Conventional PTR (CPTR) & 1.16 & 0.23 & 0.24 & 0.68 & 0.137 & 1.36 \\
\hline T2: CPTR with 12 days seedling & 1.14 & 0.27 & 0.28 & 0.72 & 0.144 & 1.33 \\
\hline T3:CPTR with spacing of $25 \mathrm{~cm} \times 25 \mathrm{~cm}$ & 1.13 & 0.24 & 0.26 & 0.69 & 0.135 & 1.30 \\
\hline T4: CPTR with 1 seedling/hill & 1.16 & 0.25 & 0.24 & 0.70 & 0.137 & 1.37 \\
\hline $\begin{array}{l}\text { T5: CPTR with } \quad \text { N-Organic: } \\
\text { inorganic::50:50 }\end{array}$ & 1.17 & 0.29 & 0.25 & 0.67 & 0.156 & 1.37 \\
\hline $\begin{array}{l}\text { T6: CPTR with Saturation water } \\
\text { management (AWD) }\end{array}$ & 1.15 & 0.24 & 0.23 & 0.71 & 0.140 & 1.27 \\
\hline $\begin{array}{l}\text { T7: CPTR with weed management } \\
\text { through mechanical rotating hoe }\end{array}$ & 1.14 & 0.23 & 0.27 & 0.69 & 0.133 & 1.32 \\
\hline T8: SRI & 1.16 & 0.25 & 0.31 & 0.76 & 0.157 & 1.38 \\
\hline $\operatorname{SEm}( \pm)$ & 0.01 & 0.02 & 0.02 & 0.024 & 0.008 & 0.04 \\
\hline $\operatorname{LSD}(p=0.05)$ & NS & NS & NS & NS & NS & NS \\
\hline
\end{tabular}

PTR = Puddled transplanted rice; CPTR = Conventional puddle transplanted rice; AWD = Alternate wetting and drying; $\mathrm{SRI}=$ System of rice intensification; $\operatorname{SEm}( \pm)=$ Standard error of mean; LSD $=$ Least significant difference 
Table.4 Effect of different crop establishment method on the nutrient uptake by grain and straw in rice crop

\begin{tabular}{|c|c|c|c|c|c|c|c|c|c|}
\hline \multirow{3}{*}{ Treatments } & \multicolumn{9}{|c|}{ Nutrient uptake, kg ha $^{-1}$} \\
\hline & \multicolumn{3}{|c|}{$\mathrm{N}$ uptake } & \multicolumn{3}{|c|}{ P uptake } & \multicolumn{3}{|c|}{ K uptake } \\
\hline & Grain & Straw & Total & Grain & Straw & Total & Grain & Straw & Total \\
\hline T1: Conventional PTR (CPTR) & 61.4 & 42.2 & 103.6 & 12.2 & 8.4 & 20.6 & 12.5 & 83.8 & 96.3 \\
\hline T2: CPTR with 12 days seedling & 64.7 & 46.9 & 111.6 & 15.3 & 9.3 & 24.7 & 15.7 & 86.3 & 102.0 \\
\hline $\begin{array}{l}\text { T3: CPTR with spacing of } \\
25 \mathrm{~cm} \times 25 \mathrm{~cm}\end{array}$ & 58.8 & 40.9 & 99.7 & 12.5 & 8.1 & 20.6 & 13.6 & 77.3 & 90.9 \\
\hline T4: CPTR with 1 seedling/hill & 61.7 & 45.0 & 106.7 & 13.6 & 8.8 & 22.3 & 13.0 & 88.3 & 101.2 \\
\hline $\begin{array}{l}\text { T5: CPTR with } \\
\text { Organic:inorganic::50:50 }\end{array}$ & 54.5 & 39.5 & 93.9 & 13.5 & 9.2 & 22.7 & 11.7 & 80.6 & 92.2 \\
\hline $\begin{array}{l}\text { T6: CPTR with Saturation } \\
\text { water management (AWD) }\end{array}$ & 50.8 & 38.0 & 88.8 & 10.4 & 7.5 & 17.8 & 10.3 & 67.9 & 78.1 \\
\hline $\begin{array}{l}\text { T7: CPTR with weed } \\
\text { management through } \\
\text { mechanical rotating hoe }\end{array}$ & 52.1 & 38.8 & 90.9 & 10.5 & 7.3 & 17.8 & 12.4 & 73.7 & 86.1 \\
\hline T8: All component of SRI & 70.0 & 50.5 & 120.5 & 15.3 & 10.5 & 25.8 & 18.7 & 92.5 & 111.3 \\
\hline $\operatorname{SEm}( \pm)$ & 2.8 & 2.4 & 4.1 & 1.1 & 0.6 & 1.4 & 1.3 & 4.6 & 5.1 \\
\hline $\operatorname{LSD}(\mathbf{P}=\mathbf{0 . 0 5})$ & 8.4 & 7.4 & 12.3 & 3.2 & 1.9 & 4.4 & 4.0 & 13.9 & 15.5 \\
\hline
\end{tabular}

PTR $=$ Puddled transplanted rice; $\mathrm{CPTR}=$ Conventional puddle transplanted rice; AWD = Alternate wetting and drying; SRI = System of rice intensification; $\operatorname{SEm}( \pm)=$ Standard error of mean; LSD $=$ Least significant difference

Table.5 Effect of different crop establishment method on the economics of the rice crop

\begin{tabular}{|c|c|c|c|}
\hline Treatments & $\begin{array}{l}\text { Gross Return } \\
\text { (Rs/ha) }\end{array}$ & $\begin{array}{l}\text { Net Return } \\
\text { (Rs/ha) }\end{array}$ & $\begin{array}{l}\text { Return per } \\
\text { Rs invested }\end{array}$ \\
\hline T1: Conventional PTR (CPTR) & 108172 & 70866 & 1.90 \\
\hline T2: CPTR with 12 days seedling & 116281 & 78975 & 2.12 \\
\hline T3: CPTR with spacing of $25 \mathrm{~cm} \times 25 \mathrm{~cm}$ & 106146 & 68840 & 1.85 \\
\hline T4: CPTR with 1 seedling/hill & 109330 & 72024 & 1.93 \\
\hline T5: CPTR with N-Organic:inorganic::50:50 & 96326 & 35020 & 0.57 \\
\hline $\begin{array}{l}\text { T6: CPTR with Saturation water management } \\
\text { (AWD) }\end{array}$ & 90775 & 53469 & 1.43 \\
\hline $\begin{array}{l}\text { T7: CPTR with weed management through } \\
\text { mechanical rotating hoe }\end{array}$ & 94173 & 59737 & 1.73 \\
\hline T8: All component of SRI & 122650 & 64214 & 1.10 \\
\hline $\operatorname{SEm}( \pm)$ & 4477 & 4477 & 0.11 \\
\hline $\operatorname{LSD}(p=0.05)$ & 13579 & 13579 & 0.34 \\
\hline
\end{tabular}

PTR $=$ Puddled transplanted rice; CPTR $=$ Conventional puddle transplanted rice; AWD $=$ Alternate wetting and drying; $\mathrm{SRI}=$ System of rice intensification; $\mathrm{SEm}( \pm)=$ Standard error of mean; $\mathrm{LSD}=$ Least significant difference 
Similarly, the highest total K uptake $(113.3 \mathrm{~kg}$ $\mathrm{ha}^{-1}$ ) was recorded with SRI, which was found at par with CPTR with 12 days seedling (102 $\left.\mathrm{kg} \mathrm{ha}^{-1}\right)$, CPTR with 1 seedling/hill $(101.2 \mathrm{~kg}$ $\left.\mathrm{ha}^{-1}\right)$, and Conventional PTR (96.3 $\mathrm{kg} \mathrm{ha}^{-1)}$. The lowest total $\mathrm{K}$ uptake $\left(78.1 \mathrm{~kg} \mathrm{ha}^{-1}\right)$ was recorded with CPTR with Saturation water management (AWD).

According to the grain yield of rice crop the nutrient uptake was also varied among the treatments. The highest $\mathrm{N}, \mathrm{P}$ and $\mathrm{K}$ uptake were recorded in the SRI treatment where the maximum productivity was noticed. The SRI recorded significantly higher $\mathrm{P}$ and $\mathrm{K}$ uptake for grain, straw and total than the other treatments. However, the total $\mathrm{N}$ uptake was found statistically similar in SRI (T8) and CPTR with 12 days old seedlings (T2). This might be due to increase in grain and straw yield which resulted in the increase in $\mathrm{N}$ uptake (Vishwakarma et al., 2016). The Highest nutrient uptake in SRI was due to water management in SRI through AWD, enhanced the microbial solubilisation of phosphorous which resulted in the highest $\mathrm{P}$ uptake (Vishwakarma et al., 2016). Jana et al., (2015) reported that the nutrient uptake was highest in the SRI as compared to the transplanted rice because of the better soil conditions in SRI practice.

\section{Economics}

The highest Gross Return (Rs. 122650 ha $^{-1}$ ) was recorded with SRI, which was found at par with CPTR with 12 days seedling (Rs. $116281 \mathrm{ha}^{-1}$ ) and CPTR with single seedling/hill (109330). The lowest Gross Return (90775) was recorded with CPTR with Saturation water management (AWD).

Similarly, the highest Net Return (Rs. 78975 $\mathrm{ha}^{-1}$ ) was recorded with CPTR with 12 days seedling, which was found at par with Conventional PTR(70866), CPTR with 1 seedling/hill (72024) and CPTR with spacing of $25 \mathrm{~cm} \times 25 \mathrm{~cm}$ (Rs. $68840 \mathrm{ha}^{-1}$ ). The lowest Net Return (Rs. 35020 ha $^{-1}$ ) was recorded with CPTR with N organic: inorganic:: 50:50. Similarly, the highest Return per Rs. invested (2.12) was recorded with CPTR with 12 days seedling, which was found at par with conventional PTR (1.90), CPTR with single seedling/hill (1.93), and CPTR with spacing of $25 \mathrm{~cm} \times 25 \mathrm{~cm}(1.85)$. The lowest Return per Rs invested (0.57) was recorded with CPTR with $\mathrm{N}$ organic: inorganic:: 50:50.Gross Returns(Rs.122650/ha) were obtained highest in the SRI, which was statistically at par with CPTR with 12 days seedling (Rs.116281/ha) and CPTR with1 seedling/hill (Rs.109330/ha). SRI has produced highest grain yield which has resulted in the highest gross returns. These results are in conformity with Sudhakar et al., (2017). The highest Net Returns(Rs.78975/ha) was recorded with CPTR with 12 days seedling, which was statistically at par with Conventional PTR(Rs.70866/ha), CPTR with 1 seedling/hill (Rs.72024/ha) and CPTR with spacing of 25 $\mathrm{cm} \times 25 \mathrm{~cm}$ (Rs.68840/ha) and the highest Return per Rupee invested (2.12) was recorded with CPTR with 12 days seedling, which was found at par with Conventional PTR (1.90), CPTR with 1 seedling/hill (1.93), and CPTR with spacing of $25 \mathrm{~cm} \times 25 \mathrm{~cm}$ (1.85). This is because of less cost of cultivation in CPTR, CPTR with 1 seedling/hill, CPTR with spacing of $25 \mathrm{~cm} \mathrm{x}$ $25 \mathrm{~cm}$ and CPTR with 12 days seedling and higher gross returns which has resulted in the highest net returns as well as Return per Rs invested. These results are conformity with the findings of Kumar and Kumar (2018), Sudhakar et al., (2017) and Mohandas et al., (2015).

In conclusion the Based on these finding we can suggest the farmer in our country to go for partial implementation of SRI i.e., 12 days old seedling with single seedling/hill in 
transplanted kharif rice if practicing all principles of SRI is not possible. But the highest gross return (Rs $122650 \mathrm{ha}^{-1}$ ) was recorded in the SRI, which was statistically at par with CPTR with 12 days seedling. However, the highest net return and $\mathrm{B}: \mathrm{C}$ ratio were recorded Rs $78975 \mathrm{ha}^{-1}$ and 2.12 respectively in the CPTR with 12 days seedling.

\section{Acknowledgments}

First and foremost, I stand obliged and indebted to my advisor Dr. Mainak Ghosh (Assistant Professor-cum-Jr. Scientist) Department of Agronomy for his inspiring guidance, unflinching support and constant encouragement throughout the course of investigation as well as the preparation of this manuscript.

\section{References}

Annual report of Ministry of Agriculture and Farmers' Welfare, 2017-18.

Bouman, BAM., Humphrey, E., Tuong, TP. and Barker, R. 2007. Rice and water. Advances in Agronomy 92(4):187237.

Dinesh, D., Baskar, A. and Rajan, K. 2017. Effect of cultivation methods and nitrogen management strategies on growth and yield of rice (Oryza sativa $L$.) grown in coastal alluvial soils of southern India. International Journal of Current Microbiology and Applied Sciences 6(3):2176-2187.

Duttarangvi, S., Mahendra, K., Desai, BK., Pujari, BT., Tirupatiah, K., Koppalkar, BG., umesh,MKN. and Yella, RK. 2016. influence of crop establishment method, irrigation water level and weed management practices on growth and yield of rice (Oryza sativa L.). Indian Journal of Agronomy 62(2):174-178.
FAOSTAT (2015). Kishor ,M., Praveen, RV., Ramulu, V., Avil, KK. and Uma, DM. 2017.Standardization of alternate wetting and drying (AWD) method of water management in low land rice (Oryza sativa L.) International Journal of Plant Production 11(4):515-532.

Latif A (2010) A study on effectiveness of field water tube as a practical indicator to irrigate SRI rice in alternate wetting and drying irrigation management practice. M.Sc. Thesis, The University of Tokyo, Japan.

Mohandas, S., Saviour, MN. and Pandian, BJ. 2015. Performance of SRI under different $\mathrm{N}$ sources in sandy loam soils of Agniyar sub-basin Indian Journal of Agriculture Research 49(2):170-174.

Palanisami, K., Karunakaran, KR., Amarasinghe, U. and Ranganathan, CR. 2013. Doing different things or doing it differently? rice intensification practices in 13 States of India. Economic \&Political Weekly XLVIII 8: 51-58.

Praneeth, SDV., Reddy, V., Mahendra, KR., Rao, PR., Latha, PC. and Ramesh, T. 2017.comparison of leaf growth in different crop establishment method with nitrogen management practices, International Journal pure applied BioScience 5(4):1376-1381.

Reuben, P., Katambara, Z., Kahimba, CF., Mahoo1, FH., Mbungul, BW., Mhenga1, F., Nyarubamba, A. and Maugo, M. 2016. Influence of transplanting age on paddy yield under the system of rice intensification. Agricultural Sciences 7:154-163.

Shobarani, N., Prasad, GSV., Prasad, ASR., Sailaja, B., Muthuraman, P., Numeera, S. and Viraktamath, BC. 2010. Rice Almanac-India. DRR Technical Bulletin No 5, Directorate of Rice Research, Rajendranagar, Hyderabad. Sudhakar, TM., Srinvas, A., Kumar, RM., 
Ram, PT. and Rajanna, GA. 2017. Energy saving and profitability of rice (Oryza sativa L.) under mechanized and conventional system of rice intensification. Indian Journal of Agronomy 62(2):174-179.

\section{How to cite this article:}

Rahul Kumar, Manish Raj, Kanhaiya Lal, Aditya Shri, Ajay Kumar and Priyanka Kumari. 2020. Impact of System of Rice Intensification (SRI) Components on Nutrient Content, Nutrient Uptake, Soil Parameters and Economics over Conventional Puddled Transplanted Rice. Int.J.Curr.Microbiol.App.Sci. 9(11): 349-358.

doi: https://doi.org/10.20546/ijcmas.2020.911.042 